\title{
EFEKTIVITAS PENERAPAN MODEL KOOPERATIF TIPE NUMBERED HEADS TOGETHER (NHT) DENGAN PENDEKATAN QUANTUM TEACHING DALAM PEMBELAJARAN MATEMATIKA SISWA SMP NEGERI 1 BINAMU KABUPATEN JENEPONTO
}

\author{
Husriani Husain ${ }^{1}$, Syaharuddin ${ }^{2}$ \\ Pendidikan Matematika ${ }^{1,2}$, STKIP YAPTI Jeneponto ${ }^{1,2}$ \\ $\underline{\text { husrianihusain23@gmail.com }}^{1}$
}

\begin{abstract}
Abstrak
Penelitian ini bertujuan untuk mengetahui gambaran Efektivitas Model Kooperatif Tipe Numbered Heads Together (NHT) dengan Pendekatan Quantum Teaching dalam Pembelajaran Matematika pada siswa Kelas VII.1 SMP Negeri 1 Binamu Kabupaten Jeneponto. Penelitian ini merupakan penelitian kuantitatif deskriptif yang fokus pada Efektivitas Model Kooperatif Tipe Numbered Heads Together (NHT) dengan Pendekatan Quantum Teaching dalam Pembelajaran Matematika pada Siswa Kelas VII SMP Negeri 1 Binamu Kabupaten Jeneponto. Populasi dalam penelitian ini adalah seluruh siswa kelas VII SMP Negeri 1 Binamu Kabupaten Jeneponto yang terbagi menjadi 8 kelas dengan jumlah siswa 252 orang. Sampel penelitian adalah siswa kelas VII.1 berjumlah 31 orang siswa yang dipilih menggunakan teknik purposive sampling dengan mempertimbangkan bahwa siswa tersebut pernah diajar menggunakan Model pembelajaran Kooperatif tipe Numbered Heads Together (NHT) dengan Pendekatan Quantum Teaching. Teknik yang digunakan untuk mengumpulkan data dalam penelitian ini yaitu dokumentasi, wawancara dan kuesioner. Analisis data menggunakan analisis deskriptif. Hasil penelitian dan analisis data yang diperoleh dapat ditarik kesimpulan bahwa penerapan model kooperatif tipe Numbered Heads Together (NHT) dengan pendekatan Quantum Teaching untuk siswa kelas VII.1 SMP Negeri 1 Binamu Kabupaten Jeneponto memenuhi kriteria efektif.
\end{abstract}

Kata Kunci : Quantum Teaching; hasil belajar; respons.

\section{A. Pendahuluan}

Pendidikan merupakan upaya untuk mengembangkan kemampuan individu dalam mengantisipasi kemungkinan-kemungkinan yang sedang atau yang akan terjadi. Pendidikan tidaklah dipandang hanya sebagai proses mentransfer ilmu pengetahuan kepada siswa, tetapi lebih ditekankan ke arah untuk mempersiapkan mental siswa dalam mengarungi kehidupan kelak dikemudian hari agar dapat memecahkan segala persoalan yang akan dihadapi (Astutik, 2017). Oleh karena ini 
pendidikan yang diselenggarakan harus dapat memberikan bekal, sehingga siswa memiliki kemampuan dan keterampilan dalam mengikuti perkembangan ilmu pengetahuan dan teknologi.

Salah satu mata pelajaran yang berperan penting dalam pendidikan adalah matematika. Pelajaran matematika diajarkan pada setiap jenjang pendidikan dengan tujuan untuk melatih siswa menggunakan logika, belajar befikir secara praktis, bersikap kritis dan kreatif serta sistematis dalam kehidupan sehari-hari dan kemamuan bekerja sama yang efektif. Namun kenyataan di lapangan, pelajaran matematika masih dianggap sebagai momok yang menakutkan juga membosankan sehingga pelajaran matematika tidak disenangi dan tidak diperdulikan.

Hasil observasi dan wawancara dengan beberapa guru mata pelajaran matematika yang mengampu kelas VII di SMP Negeri 1 Binamu kabupaten Jeneponto, diperolah informasi bahwa masih banyak siswa yang kurang terlibat aktif dalam proses pembelajaran. Hanya siswa yang berkemampuan tinggi saja yang berani untuk bertanya dan menjawab pertanyaan guru serta masih banyak siswa yang tingkat penguasaan materinya belum tuntas terhadap pelajaran matematika. Siswa yang belum tuntas harus mengikuti program remedial.

Menurut guru yang bersangkutan dan pengamataan peneliti, penyebab rendahnya hasil belajar matematika adalah kurangnya keefektifan siswa saat mengikuti proses pembelajaran, yang mengakibatkan rendahnya pemahaman siswa terhadap mata pelajaran matematika. Selain itu, rendahnya hasil belajar matematika yang dicapai siswa juga dipengaruhi oleh penerapan model pembelajaran yang kurang tepat. Hal ini sejalan dengan pendapat Irawan (2017) yang menjelaskan bahwa model pembelajaran sangat berpengaruh dalam upaya meningkatkan prestasi belajar matematika.

Guru memainkan peran penting dalam proses pembelajaran. Metode pengajaran yang dipilih harus sejalan dengan topik pelajaran yang akan disajikan dikarenakan penerapan metode pengajaran yang tepat akan membantu keberhasilan tujuan pembelajaran (Maman, M., \& Rajab, A. A, 2016). Hal ini sejalan dengan pendapat Nursyamsi (2016) yang menjelaskan bahwa metode pembelajaran yang membuat 
siswa lebih aktif, menyenangkan, dan efektif perlu dilaksanakan dalam rangka mencapai tujuan pembelajaran. Ada banyak metode yang dapat digunakan untuk membuat siswa aktif dalam proses belajar mengajar, salah satunya adalah metode Numbered Heads Together (NHT) (Maman, M., \& Rajab, A. A, 2016).

Model pembelajaran kooperatif tipe Numbered Heads Together (NHT) ini pertama kali dikembangkan Spenser Kagen untuk melibatkan bamyak siswa dalam menelaah materi yang tercakup dalam suatu pembelajaran (Lorina, 2012). Pembelajaran Numbered Heads Together (NHT) merupakan tipe pembelajaran yang dirancang untuk mempengaruhi pola interaksi siswa dan memiliki tujuan untuk meningkatkan semangat kerjasama dalam kelompok serta memberikan kesempatan kepada siswa untuk saling membagi ide-ide dan mendiskusikan jawaban yang paling tepat (Lorina, 2012).

Model pembelajaran kooperatif tipe Numbered Heads Together (NHT) adalah model pembelajaran yang dapat menghilangkan kesenjangan antara siswa yang cerdas dan tidak cerdas sehingga, setiap siswa akan ikut aktif dalam diskusi (Irawan, 2017). Selain itu, Hunter, W. C, dkk (2016) menjelaskan bahwa kegiatan belajar mengajar dengan penerapan model Numbered Heads Together (NHT) mempengaruhi hasil belajar siswa dalam proses belajar mengajar.

Menurut Miftahul A'la (Farahsanti, 2012: 42) kelebihan pembelajaran kooperatif tipe Numbered Heads Together (NHT) yaitu setiap siswa menjadi siap semua, dapat melakukan diskusi dengan sungguh-sungguh, dan siswa yang pandai dapat mengajari siswa yang kurang pandai. Adapun kelemahan model pembelajaran kooperatif tipe Numbered Heads Together (NHT) adalah tidak terlalu cocok untuk jumlah siswa yang banyak karena membutuhkan waktu yang lama, dan tidak semua anggota kelompok dipanggil guru. Untuk mengatasi kelemahan tersebut, seorang guru dapat membuat catatan terkait dengan nomor-nomor yang sudah dipanggil dalam setiap pertemuan. Untuk nomor yang belum dipanggil, dapat dipanggil pada pertemuan berikutnya.

Agar penerapan model pembelajaran kooperatif tipe Numbered Heads Together (NHT) lebih efektif dan menyenangkan, maka model pembelajaran kooperatif tipe Numbered Heads Together (NHT) dikombinasikan dengan pendekatan Quantum 
Teaching. Pendekatan Quantum Teaching adalah pendekatan pembelajaran yang mengajak siswa untuk berperan aktif dalam belajar dengan menggunakan pengetahuan dasar siswa untuk mengembangkan pengetahuan mereka dan memperoleh pengetahuan baru (Ulandari, 2017).

Unsur pembelajaran pendekatan Quantum Teaching dapat dibagi menjadi dua kategori seperti konteks dan isi. Kategori konteks meliputi: suasana hati, suasana lingkungan belajar yang teratur, pembelajaran dasar, presentasi dan fasilitas. Sedangkan kategori isi meliputi: guru akan menemukan keterampilan bagaimana menyajikan kurikulum, siswa akan menemukan strategi pembelajaran yang dibutuhkan oleh siswa, yaitu: presentasi yang baik, fasilitas dinamis, keterampilan belajar untuk belajar dan keterampilan hidup (Ulandari, 2017).

Pendekatan Quantum Teaching merupakan pendekatan pembelajaran yang membentuk suasana belajar menjadi lebih nyaman dan menarik (Rezeka, dkk 2016). Menurut DePorter, dkk (2010: 39) Quantum Teaching mempunyai kerangka belajar mengajar yang lebih dikenal sebagai TANDUR yaitu Tumbuhkan, Alami, Namai, Demonstrasikan, Ulangi, dan Rayakan. Selain itu, Quantum Teaching menggunakan satu set prinsip yang disebut delapan kunci keunggulan. Delapan kunci keunggulan Quantum Teaching adalah integritas, kegagalan awal kesuksesan, bicaralah dengan niat baik, hidup di saat ini, komitmen, tanggung jawab, luwes, dan keseimbangan.

Model kooperatif tipe Numbered Heads Together (NHT) dengan pendekatan Quantum Teaching adalah model yang dirancang untuk mendidik kerja sama kelompok dan interaksi antar siswa untuk menumbuhkan pembelajaran efektif, memudahkan proses belajar lewat pemaduan unsur seni dalam proses belajar sehingga belajar akan terasa lebih menyenangkan, siswa lebih aktif sehingga dapat meningkatkan hasil belajar matematika dan aktivitas siswa.

Adapun langkah-langkah pembelajaran kooperatif tipe Numbered Heads Together (NHT) dengan pendekatan Quantum Teaching yang dilakukan oleh guru mata pelajaran matematika kelas VII.1 SMP Negeri 1 Binamu Kabupaten jeneponto yaitu: (1) guru membuat RPP dan LKS yang sesuai dengan model pembelajaran Numbered Heads Together (NHT) dengan pendekatan Quantum Teaching, (2) sebelum 
proses belajar mengajar dimulai, diputarkan musik atau lagu-lagu riang atau kesukaan siswa dengan volume sedang agar siswa merasakan suasana yang nyaman dan santai, (3) guru menyampaikan tujuan dan memotivasi siswa, (4) siswa dibagi dalam beberapa kelompok secara heterogen. Setiap siswa dalam kelompok mendapat nomor yang berbeda satu sama lain, (5) siswa diminta duduk berdekatan dengan teman sekelompoknya, (6) guru mempresentasikan materi secara garis besar di depan kelas dan menjelaskan cara mengerjakan LKS, (7) guru memberikan kesempatan kepada siswa untuk bertanya, (8) guru memberikan tugas yang harus dikerjakan secara berkelompok, (9) selama siswa berdiskusi, diputarkan musik-musik instrumentalia, (10) siswa mendiskusikan persoalan yang diberikan dan bersama-sama memecahkan persoalan yang diberikan, (11) selama diskusi kelompok, guru bertindak sebagai motivator dan fasilitator, (12) kelompok merangkum semua hasil diskusi dan memastikan setiap anggota kelompok mengetahui atau memahami hasil diskusi tersebut, (13) setelah diskusi kelompok, musik dimatikan, guru memanggil salah satu nomor, (14) siswa dengan nomor yang dipanggil melaporkan hasil diskusi kelompoknya. Setiap siswa yang sudah menyelesaikan presentasinya, guru memberikan pujian, (15) siswa dari kelompok lain yang masih belum paham atau berbeda pendapat menyampaikan pertanyaan atau pendapatnya, yang dibimbing oleh guru, (16) guru bersama dengan siswa membuat rangkuman tentang hasil presentasi siswa, (17) guru mengadakan kuis atau tugas secara individu, (18) guru memberikan pujian kepada kelompok terbaik.

Hasil penelitian Wahyuddin (2017) menyatakan bahwa terjadi peningkatan hasil belajar dari siklus I ke siklus II setelah diadakan pengembangan pembelajaran kooperatif tipe NHT, terjadi perubahan sikap siswa selama proses pembelajaran dan dapat meningkatkan rasa percaya diri siswa untuk bertanya baik kepada guru maupun kepada temannya. Sedangkan penelitian Yuhasriati dan Yulianti (2015) menunjukkan bahwa pembelajaran persamaan linear satu variabel dengan model Quantum Teaching di kelas VII MTsN Tungkop Aceh Besar dapat membantu siswa untuk mencapai penguasaan belajar dan selama proses pembelajaran, siswa juga menunjukkan sikap bertanggung jawab dan komitmen dalam penguasaan belajar. 
Dari uraian di atas, maka peneliti tertarik melakukan penelitian yang bertujuan untuk mengetahui gambaran Efektivitas Model Kooperatif Tipe Numbered Heads Together (NHT) dengan Pendekatan Quantum Teaching dalam Pembelajaran Matematika pada siswa Kelas VII.1 SMP Negeri 1 Binamu Kabupaten Jeneponto.

\section{B. Metode Penelitian}

Penelitian ini merupakan penelitian kuantitatif deskriptif untuk mengetahui gambaran efektivitas model kooperatif tipe Numbered Heads Together (NHT) dengan pendekatan Quantum Teaching. Penelitian dilaksanakan di SMP Negeri 1 Binamu kabupaten Jeneponto. Populasi dalam penelitian ini adalah seluruh siswa kelas VII SMP Negeri 1 Binamu Kabupaten Jeneponto yang terbagi menjadi 8 kelas dengan jumlah siswa 252 orang. Sampel penelitian adalah siswa kelas VII.1 berjumlah 31 orang siswa yang dipilih menggunakan teknik purposive sampling dengan mempertimbangkan bahwa siswa tersebut pernah diajar menggunakan Model pembelajaran Kooperatif tipe Numbered Heads Together (NHT) dengan Pendekatan Quantum Teaching.

Variabel dalam penelitian ini adalah efektivitas pembelajaran dan bentuk variabelnya adalah variabel tunggal. Artinya tidak mencari pengaruh atau hubungan variabel lain tetapi bermaksud mendeskripsikan tentang efektivitas model kooperatif tipe Numbered Heads Together (NHT) dengan pendekatan Quantum Teaching.

Instrument yang digunakan dalam penelitian ini adalah kuesioner yang dibagikan secara online. Teknik yang digunakan untuk mengumpulkan data dalam penelitian ini yaitu kuesioner, dokumentasi dan wawancara.

Data hasil penelitian yang telah didapatkan diolah menggunakan analisis deskriptif kuantitatif dengan cara sebagai berikut :

1. Analisis Data Nilai Hasil Belajar Matematika Siswa yang Diajar dengan Menggunakan Model Pembelajaran Kooperatif tipe Numbered Heads Together (NHT) dengan Pendekatan Quantum Teaching didapat dengan mengelompokkan nilai hasil belajar yang diperoleh siswa tersebut untuk memperoleh kriteria efektivitas hasil belajar sesuai dengan kategori yang diajukan oleh Kartika Budi 
(Nuhuyanan, 2019 : 53) untuk melihat persentase ketuntasan hasil belajar siswa.

Tabel tersebut sebagai berikut :

Tabel 1 Kriteria Efektivitas Hasil Belajar secara Kualitatif

\begin{tabular}{|c|c|c|c|c|c|}
\hline \multicolumn{5}{|c|}{ Jumlah yang Memperoleh Nilai } & \multirow{2}{*}{ Efektivitas } \\
\hline$\geq 80$ & $\geq 70$ & $\geq 60$ & $\geq \mathbf{5 0}$ & $\geq 40$ & \\
\hline$\geq 75 \%$ & & & & & Sangat Tinggi \\
\hline \multirow[t]{4}{*}{$<75 \%$} & $\geq 75 \%$ & & & & Tinggi \\
\hline & $<75 \%$ & $\geq 65 \%$ & & & Cukup \\
\hline & & $<65 \%$ & $\geq 65 \%$ & & Rendah \\
\hline & & & $<65 \%$ & & Sangat Rendah \\
\hline
\end{tabular}

Sumber : Kartika Budi (Nuhuyanan, 2019 : 53)

2. Analisis hasil wawancara dilakukan dengan cara menarik poin-poin yang dianggap penting dalam wawancaara tersebut, selanjutnya dibuat kesimpulannya secara deskriptif.

3. Analisis Data Respons Siswa terhadap Model Pembelajaran Kooperatif tipe Numbered Heads Together (NHT) dengan Pendekatan Quantum Teaching dilakukan dengan menjumlahkan skor setiap item pernyataan. Kuesioner menggunakan skala likert dengan penilaian skor : Sangat Setuju $=5$; Setuju $=4$; Netral/Biasa $=3$; Tidak Setuju $=2$; Sangat Tidak Setuju $=1$. Setelah mendapatkan total skor dari setiap item pernyataan, kemudian dicari nilai persentase dari masingmasing item pernyataan, dari hasil perhitungan yang telah diperoleh, kemudian dikonversikan ke dalam klasifikasi berikut

Tabel 2. Klasifikasi TCR

\begin{tabular}{ccc}
\hline No & Persentasi Pencapaian & Kriteria \\
\hline 1 & $85 \%-100 \%$ & Sangat Baik \\
\hline 2 & $66 \%-84 \%$ & Baik \\
\hline 3 & $51 \%-65 \%$ & Cukup Baik \\
\hline 4 & $36 \%-60 \%$ & Kurang Baik \\
\hline 5 & $0 \%-35 \%$ & Tidak Baik \\
\hline \multicolumn{2}{c}{ Sumber : Sugiyono (2012:207) }
\end{tabular}

4. Analisis Efektivitas Pembelajaran Matematika dengan menggunakan model kooperatif tipe NHT dengan pendekatan Quantum Teaching. Efektivitas pembelajaran melalui penerapan model kooperatif tipe NHT dengan pendekatan Quantum Teaching jika 
a. Ketuntasan belajar, pembelajaran dapat dikatakan tuntas apabila sekurangkurangnya $75 \%$ dari jumlah siswa telah memperoleh nilai $=60$ dalam peningkatan hasil belajar.

b. Metode pembelajaran dikatakan efektif meningkat hasil belajar siswa menunjukkan perbedaan antara pemahaman awal dengan pemahaman setelah pembelajaran.

c. Metode pembelajaran dikatakan efektif dapat meningkatkan minat dan motivasi apabila setelah pembelajaran siswa menjadi lebih termotivasi untuk belajar lebih giat dan memperoleh hasil belajar yang lebih baik. Serta siswa belajar dalam keadaan menyenangkan (Muhli, 2012:10).

\section{Hasil Penelitian dan Pembahasan}

\section{Hasil Belajar Matematika Siswa yang Diajar dengan Penerapan Model} Pembelajaran Kooperatif tipe Numbered Heads Together (NHT) dengan Pendekatan Quantum Teaching KKM = 75 dapat dilihat pada tabel berikut :

Tabel 3. Analisis Data Tes Hasil Belajar Siswa

\begin{tabular}{cccc}
\hline No urut. & Siswa & Total Skor & Keterangan \\
\hline 1. & S1 & 92 & Tuntas \\
\hline 2. & S2 & 80 & Tuntas \\
\hline 3. & S3 & 72 & Tidak Tuntas \\
\hline 4. & S4 & 73 & Tidak Tuntas \\
\hline 5. & S5 & 80 & Tuntas \\
\hline 6. & S6 & 89 & Tuntas \\
\hline 7. & S7 & 81 & Tuntas \\
\hline 8. & S & 84 & Tuntas \\
\hline 9. & S9 & 91 & Tuntas \\
\hline 10. & S10 & 91 & Tuntas \\
\hline 11. & S11 & 92 & Tuntas \\
\hline 12. & S12 & 70 & Tidak Tuntas \\
\hline 13. & S13 & 80 & Tuntas \\
\hline 14. & S14 & 79 & Tuntas \\
\hline 15. & S15 & 78 & Tuntas \\
\hline 16. & S16 & 85 & Tuntas \\
\hline 17. & S17 & 88 & Tuntas \\
\hline 18. & S18 & 83 & Tuntas \\
\hline 19. & S19 & 89 & Tuntas \\
\hline 20. & S20 & 83 & Tuntas \\
\hline 21. & S21 & 83 & Tuntas \\
\hline 22. & S22 & 92 & Tuntas \\
\hline 23. & S23 & 83 & Tuntas
\end{tabular}




\begin{tabular}{cccc}
\hline No urut. & Siswa & Total Skor & Keterangan \\
\hline 24. & S24 & 81 & Tuntas \\
\hline 25. & S25 & 91 & Tuntas \\
\hline 26. & S26 & 80 & Tuntas \\
\hline 27. & S27 & 88 & Tuntas \\
\hline 28. & S28 & 84 & Tuntas \\
\hline 29. & S29 & 91 & Tuntas \\
\hline 30. & S30 & 84 & Tuntas \\
\hline 31. & S31 & 91 & Tuntas
\end{tabular}

Dari data tersebut diperoleh bahwa siswa yang tuntas sebanyak 28 siswa dengan persentase 90,32\% sedangkan yang tidak tuntas sebanyak 3 orang siswa dengan persentase $9,68 \%$. Selanjutnya, nilai yang diperoleh siswa tersebut dikelompokkan dengan merujuk pada Tabel 1 untuk memperoleh kriteria efektivitas hasil belajar sebagai berikut :

Tabel 4. Persentase Nilai yang diperoleh Siswa

\begin{tabular}{ccc}
\hline Nilai & Jumlah yang Memperoleh Nilai & $\begin{array}{c}\text { Persentase } \\
(\boldsymbol{\%})\end{array}$ \\
\hline 100 & 0 & 0 \\
\hline 90 & 8 siswa & 25,81 \\
\hline 80 & 18 siswa & 58,06 \\
\hline 70 & 5 siswa & 16,13 \\
\hline 60 & 0 & 0 \\
\hline 50 & 0 & 0 \\
\hline 40 & 0 & 0
\end{tabular}

Berdasarkan tabel 1 Kriteria Efektivitas Hasil Belajar Siswa di atas, diperoleh bahwa secara keseluruhan hasil belajar matematika siswa dengan menggunakan model pembelajaran kooperatif tipe Numbered Heads Together (NHT) dengan Pendekatan Quantum Teaching termasuk dalam kriteria efektivitas sangat tinggi (83,87\%).

Hasil Wawancara dengan Guru Mata Pelajaran Matematika yang pernah Menggunakan Model Kooperatif tipe Numbered Heads Together (NHT) dengan pendekatan Quantum Teaching dapat dilihat pada tabel berikut :

Tabel 5 Hasil Wawancara dengan Guru Mata Pelajaran Matematika

\begin{tabular}{|c|c|c|}
\hline No. & Pertanyaan & Jawaban \\
\hline 1. & $\begin{array}{l}\text { Bagaimana keadaan kelas dan siswa } \\
\text { tempat ibu mengajar? }\end{array}$ & $\begin{array}{l}\text { Berdasarkan sistem kurikulum baru yang } \\
\text { ditetapkan pemerintah, maka jumlah murid di } \\
\text { sekolah kami masing-masing berjumlah } 30 \text { orang } \\
\text { per kelas dan suasana pembelajaran di kelas } \\
\text { tergolong kondusif ketika PBM berlangsung. }\end{array}$ \\
\hline
\end{tabular}


2. Ketika melakukan PBM di kelas, apakah ibu menerapkan model pembelajaran? Bila ya, model pembelajaran apa yang ibu terapkan?
Ya, setiap saya melakukan proses pembelajaran di kelas, saya selalu menerapkan model pembelajaran agar proses pembelajaran lebih efektif dan semua siswa ikut aktif sehingga diharapkan dapat mencapai tingkat kompetensi yang diinginkan. Untuk model pembelajarannya, kadang menggunakan model pembelajaran langsung, pembelajaran kooperatif, penemuan terbimbing, pemecahan masalah, tergantung pada materi pembelajaran yang saya berikan.

3. Tadi ibu mengatakan menggunakan model pembelajaran kooperatif. Model pembelajaran kooperatif terdiri dari beberapa tipe. Kalau boleh tau salah satu tipe model pembelajaran kooperatif yang pernah ibu terapkan dalam pembelajaran matematika itu tipe yang mana?

4. Bagaimana langkah - langkah ketika menerapkan model pembelajaran kooperatif tipe Numbered Heads Together (NHT) dengan pendekatan Quantum Teaching?
Model pembelajaran kooperatif tipe Numbered Heads Together (NHT) yang saya kombinasikan dengan pendekatan Quantum Teaching.
Pertama saya membuat perangkat pembelajaran
yang sesuai dengan model pembelajaran NHT
dengan pendekatan Quantum Teaching. Sebelum PBM dimulai, diputarkan musik atau lagu-lagu riang kesukaan siswa dengan volume sedang agar siswa merasakan suasana yang nyaman dan santai, kemudian menyampaikan tujuan dan memotivasi siswa, lalu siswa dibagi dalam beberapa kelompok secara heterogen. Setiap siswa dalam kelompok mendapat nomor yang berbeda satu sama lain. Setelah itu saya menjelaskan materi pelajaran secara garis besar di depan kelas dan memberikan tugas yang dikerjakan secara berkelompok. Selama siswa berdiskusi, diputarkan musik - musik instrumentalia dan saya bertindak sebagai motivator dan fasilitator. Setelah Kelompok merangkum semua hasil diskusi dan memastikan setiap anggota kelompok memahami hasil diskusi tersebut, musik dimatikan dan saya memanggil salah satu nomor siswa dan nomor yang dipanggil melaporkan hasil diskusi kelompoknya. Setiap siswa yang sudah menyelesaikan presentasinya, saya berikan pujian lalu siswa dari kelompok lain yang belum paham atau berbeda pendapat menyampaikan pertanyaan atau pendapatnya. Setelah itu saya mengarahkan siswa membuat rangkuman tentang 


\begin{tabular}{|c|c|c|}
\hline & & $\begin{array}{l}\text { hasil presentasi siswa, lalu mengadakan kuis atau } \\
\text { tugas secara individu. Yang terakhir saya } \\
\text { memberikan pujian kepada kelompok terbaik. }\end{array}$ \\
\hline 5. & $\begin{array}{l}\text { Kesulitan atau kendala apa saja yang } \\
\text { ibu temui saat penerapan model } \\
\text { pembelajaran kooperatif tipe } \\
\text { Numbered Heads Together (NHT) } \\
\text { dengan pendekatan Quantum } \\
\text { Teaching? }\end{array}$ & $\begin{array}{l}\text { Kesulitannya jika jumlah siswanya banyak } \\
\text { karena membutuhkan waktu yang lama, } \\
\text { sedangkan waktu pembelajaran matematika rata- } \\
\text { rata hanya } 2 \times 40 \text { menit sehingga tidak semua } \\
\text { anggota kelompok dipanggil guru. }\end{array}$ \\
\hline 6. & $\begin{array}{l}\text { Bagaimana hasil belajar siswa kelas } \\
\text { VII.1 pada pelajaran Matematika } \\
\text { dengan menerapkan Model } \\
\text { pembelajaran kooperatif tipe NHT } \\
\text { dengan pendekatan Quantum Teaching. }\end{array}$ & $\begin{array}{l}\text { Penilaian hasil belajarnya memuaskan. Terjadi } \\
\text { peningkatan hasil belajar siswa kelas VII.1 } \\
\text { setelah penerapan model kooperatif tipe } \\
\text { Numbered Heads Together (NHT) dengan } \\
\text { pendekatan Quantum Teaching dalam } \\
\text { pembelajaran matematika. }\end{array}$ \\
\hline 7. & $\begin{array}{l}\text { Bagaimana aktivitas siswa kelas } \\
\text { VII.1pada pelajaran Matematika } \\
\text { dengan menerapkan Model } \\
\text { pembelajaran kooperatif tipe NHT } \\
\text { dengan pendekatan Quantum } \\
\text { Teaching? }\end{array}$ & $\begin{array}{l}\text { Sebagian besar siswa aktif dalam proses } \\
\text { pembelajaran matematika dengan penerapan } \\
\text { model kooperatif tipe Numbered Heads Together } \\
(N H T) \text { dengan pendekatan Quantum Teaching. }\end{array}$ \\
\hline 8. & $\begin{array}{l}\text { Pernahkah para siswa mengeluh } \\
\text { tentang penerapan model } \\
\text { pembelajaran kooperatif tipe NHT } \\
\text { dengan pendekatan Quantum Teaching } \\
\text { yang ibu terapkan? }\end{array}$ & $\begin{array}{l}\text { Tidak pernah. Karena penerapan model } \\
\text { pembelajaran kooperatif tipe NHT dengan } \\
\text { pendekatan Quantum Teaching dapat } \\
\text { menghilangkan kesenjangan antara siswa yang } \\
\text { cerdas dan tidak cerdas, mereka memperoleh } \\
\text { kesempatan untuk saling berbagi ide dan } \\
\text { mempertimbangkan jawaban yang paling tepat } \\
\text { dan mendapatkan kesempatan yang sama untuk } \\
\text { menunjukkan kemampuan mereka dalam } \\
\text { menjawab pertanyaan. Dengan adanya pemaduan } \\
\text { unsur seni dalam proses belajar sehingga belajar } \\
\text { juga terasa lebih menyenangkan, dapat } \\
\text { menurunkan tingkat stress serta meningkatkan } \\
\text { daya ingat bagi siswa. }\end{array}$ \\
\hline
\end{tabular}

Hasil Analisis Data Respons Siswa terhadap model Pembelajaran Kooperatif tipe Numbered Heads Together (NHT) dengan Pendekatan Quantum Teaching mengenai setiap item pernyataan dapat dilihat pada tabel berikut :

Tabel 6. Rekapitulasi Analisis Data Respons Siswa di Setiap Item Pernyataan

\begin{tabular}{ccccc}
\hline No & Pernyataan & Skor & $\begin{array}{c}\text { Persentase } \\
\text { Pencapaian }\end{array}$ & Kategori \\
\hline 1 & P1 & 147 & 94,84 & Sangat Baik \\
\hline 2 & P2 & 137 & 88,39 & Sangat Baik \\
\hline 3 & P3 & 137 & 88,39 & Sangat Baik \\
\hline 4 & P4 & 136 & 87,74 & Sangat Baik \\
\hline
\end{tabular}




\begin{tabular}{lllll}
\hline 5 & P5 & 132 & 85,16 & Sangat Baik \\
\hline 6 & P6 & 150 & 96,77 & Sangat Baik \\
\hline 7 & P7 & 145 & 93,55 & Sangat Baik \\
\hline 8 & P8 & 137 & 88,39 & Sangat Baik \\
\hline & Rata-Rata & & $\mathbf{9 0 , 4}$ & Sangat Baik \\
\hline
\end{tabular}

Berdasarkan tingkat capaian respons siswa di setiap item pernyataan maka disimpulkan bahwa respons siswa terhadap pembelajaran model kooperatif tipe Numbered Heads Together (NHT) dengan pendekatan Quantum Teaching berada pada kategori sangat baik dengan skor rata-rata 90,4. Walaupun demikian,tak dapat dipungkiri masih ada satu dua orang siswa yang merasa netral/biasa terhadap penerapan model kooperatif tipe Numbered Heads Together (NHT) dengan pendekatan Quantum Teaching.

Berdasarkan analisis data yang diperoleh, pada Tabel 3 secara keseluruhan, persentase hasil belajar siswa yang tuntas sebesar 90,32\% sedangkan siswa yang tidak tuntas (belum mencapai KKM) sebesar 9,68\%. Menurut guru matematika yang mengajar dengan penerapan model kooperatif tipe Numbered Heads Together (NHT) dengan pendekatan Quantum Teaching mengalami peningkatan hasil belajar siswa., biasanya siswa yang belum mencapai KKM sebanyak 7-8 siswa dan berjenis kelamin laki-laki dan perempuan. Sedangkan pada saat guru tersebut menerapkan model kooperatif tipe Numbered Heads Together (NHT) dengan pendekatan Quantum Teaching siswa yang belum mencapai KKM sebanyak 3 siswa dan semuanya adalah siswa laki-laki. Dugaan dari peneliti bahwa perbedaan hasil tes siswa tersebut karena siswa merasa nyaman dan santai dalam pembelajaran sebab diputarkan musik atau lagu-lagu riang kesukaan siswa dengan volume sedang, siswa juga merasa termotivasi untuk belajar dengan kekuatan AMBAK (apakah manfaatnya bagiku). Selain itu siswa yang pandai dapat mengajari siswa yang kurang pandai karena siswa saling sharing ide-ide dan memastikan semua anggota dalam kelompok paham/mengerti dengan jawaban hasil kerja kelompoknya, siswa juga melakukan diskusi dengan sungguhsungguh karena pembelajaran NHT dapat menghilangkan kesenjangan antara siswa yang cerdas dan tidak cerdas sehingga setiap siswa akan ikut aktif dalam diskusi serta setiap siswa menjadi siap semua karena setiap siswa mendapatkan nomor tertentu dan guru akan menunjuk salah satu nomor siswa secara acak untuk menjawab setiap 
pertanyaan. Ini sejalan dengan pernyataan Leasa, M., \& Corebima, A. D (2017) bahwa model pembelajaran kooperatif tipe Numbered Heads Together (NHT) memungkinkan siswa yang berkemampuan tinggi dan rendah untuk membantu dan memotivasi satu sama lain untuk meningkatkan prestasi akademik mereka.

Hasil wawancara yang dilakukan kepada guru mata pelajaran matematika yang pernah menerapkan model kooperatif tipe Numbered Heads Together (NHT) dengan pendekatan Quantum Teaching menyebutkan bahwa terjadi peningkatan hasil belajar siswa setelah penerapan model kooperatif tipe Numbered Heads Together (NHT) dengan pendekatan Quantum Teaching dan sebagian besar siswa aktif dalam proses pembelajaran matematika. Selain itu, penerapan model pembelajaran kooperatif tipe NHT dengan pendekatan Quantum Teaching juga dapat menghilangkan kesenjangan antara siswa yang cerdas dan tidak cerdas, mereka memperoleh kesempatan untuk saling berbagi ide dan mempertimbangkan jawaban yang paling tepat serta mendapatkan kesempatan yang sama untuk menunjukkan kemampuan mereka dalam menjawab pertanyaan. Dengan adanya pemaduan unsur seni dalam proses belajar sehingga belajar juga terasa lebih menyenangkan, dapat menurunkan tingkat stress dan meningkatkan daya ingat bagi siswa. Hal ini sejalan dengan yang dikemukakan oleh DePorter,dkk (2010: 112) bahwa musik dalam pendidikan dapat menata suasana hati, meningkatkan hasil belajar, dan menyoroti hal-hal penting. Selain kelebihan, terdapat pula kekurangan yaitu jika jumlah siswanya banyak karena membutuhkan waktu yang lama, sedangkan waktu pembelajaran matematika rata-rata hanya $2 \times 40$ menit sehingga tidak semua anggota kelompok dipanggil guru.

Berdasarkan rekapitulasi analisis data pada tabel 6, secara keseluruhan tanggapan siswa di setiap item pernyataan terhadap penerapan model kooperatif tipe Numbered Heads Together (NHT) dengan pendekatan Quantum Teaching termasuk dalam kategori sangat baik dengan rata-rata persentase pencapaian 90,4. Hal ini sesuai dengan pendapat Layli (2014) mengatakan bahwa respons siswa yang positif terhadap pembelajaran juga diperhitungkan dalam menentukan kualitas pembelajaran. Walaupun demikian,tak dapat dipungkiri masih ada satu dua orang siswa yang merasa 
netral/biasa terhadap penerapan model kooperatif tipe Numbered Heads Together (NHT) dengan pendekatan Quantum Teaching.

Dengan demikian berdasarkan uraian di atas, dapat dikemukakan bahwa penerapan model kooperatif tipe Numbered Heads Together (NHT) dengan pendekatan Quantum Teaching untuk siswa kelas VII.1 SMP Negeri 1 Binamu Kabupaten Jeneponto memenuhi kriteria keefektifan dalam penelitian ini. Hasil penelitian di atas, semakin memperkuat penelitian yang dilakukan oleh Listiani dkk (2016) mengatakan bahwa model pembelajaran NHT-QL memberikan prestasi belajar matematika yang lebih baik dari model pembelajaran TPS-QL dan model pembelajaran klasikal. Sedangkan hasil penelitian yang telah dilakukan oleh Atiyah, Nikmatul (2018) menunjukkan bahwa Pembelajaran kooperatif tipe Numbered Heads Together (NHT) dengan pendekatan Quantum Learning dapat meningkatkan keaktifan dan berdampak positif terhadap hasil belajar matematika.

\section{Kesimpulan}

Berdasarkan hasil penelitian dan pembahasan, maka kesimpulan yang dapat ditarik dari penelitian ini adalah pembelajaran dengan menggunakan model kooperatif tipe NHT dengan pendekatan Quantum Teaching efektif diterapkan di kelas VII.1 SMP Negeri 1 Binamu Kabupaten Jeneponto.

\section{Daftar Pustaka}

Astutik, Wiji (2017). Model Quantum Learning untuk Meningkatkan Hasil Belajar Pecahan. Briliant: Jurnal Riset dan Konseptual, 2(2), 124 - 129.

Atiyah, Nikmatul, dkk. (2018). Penerapan Model Pembelajaran Kooperatif Tipe Numbered Heads Together (NHT) dengan Pendekatan Quantum Learning untuk Meningkatkan Keaktifan Belajar Matematika siswa kelas VII.G SMP Negeri 1 Ngawen Klaten. Jurnal Pendidikan Matematika dan Matematika (JPMM) Solusi Vol.II No.4,307-314.

DePorter, Bobbi dkk. (2010). Quantum Teaching: Orchestrating Student Succes.. Cet. II; Bandung: Kaifa.

Farahsanti, Isna. (2012). Efektivitas Model Pembelajaran Kooperatif Tipe Numbered Heads Together (NHT) dengan Pendekatan Quantum Learning pada Mata Materi Persamaan Garis Lurus Ditinjau dari Kecerdasan Matematis Logis 
Siswa SMP Negeri di Kabupaten Sukoharjo Tahun Pelajaran 2011/2012. Tesis tidak Diterbitkan: Universitas Sebelas Maret.

Hunter, W.C, et al. (2016). Consultants and Coteachers Affecting Students Outcomes with Numbered Heads Together: Keeping All Engaged. J. Educ. Psychol. Consult., pp 1-14

Irawan, A, et al (2017). Experimentation of cooperative learning model Numbered Heads Together (NHT) type by concept maps and Teams Games Tournament (TGT) by concept maps in terms of students logical mathematics intellegences. Journal of Physics: Conference Series, 855, 012019.

Layli, S. (2014). Penerapan Model Pembelajaran Berdasarka Masalah pada Materi Teorema Pythagoras. Tesis tidak Diterbitkan: UNS.

Leasa, M., \& Corebima, A. D. (2017). The effect of numbered heads together (NHT) cooperative learning model on the cognitive achievement of students with different academic ability. Journal of Physics: Conference Series, 795, 012071.

Listiani, T, dkk. (2016). Eksperimentasi Model Pembelajaran Kooperatif Tipe Numbered Heads Together dan Think Pair Share dengan Quantum Learning Ditinjau dari Kecerdasan Matematis Logis Siswa SMP Se-Kabupaten Magelang Tahun Pelajaran 2014/2015. Jurnal Elektronik Pembelajaran Matematika, 4(1).

Lorina, Pirade. (2012). Penerapan Model Pembelajaran Kooperatif Tipe Numbered Head Together Berbantuan Media Gambar untuk Meningkatkan Hasil Belajar Siswa Pada Mata Pelajaran IPA Di Kelas IV SDN No. 1 Tanjung Padang: Palu. Universitas Tadulako . Elementary School of Education E-Journal, Media Publikasi Ilmiah Prodi PGSD, 2(2).

Maman, M., \& Rajab, A. A. (2016). The Implementation of Cooperative Learning Model 'Number Heads Together (NHT) in Improving the Students' Ability in Reading Comprehension. International Journal of Evaluation and Research in Education (IJERE), 5(2), 174-180.

Muhli, Ahmad. (2012). Efektivitas Pembelajaran; Jakarta: Wordpress.

Nuhuyanan, T Agnes. 2019. Keefektifan Pembelajaran Matematika dengan Memanfaatkan Aplikasi Edmodo sebagai Media Bantu Diskusi Kelas XI MIPA 4 SMA Negeri 8 Yogyakarta Tahun Ajaran 2018/2019. Skripsi tidak Diterbitkan: Universitas Sanata Dharma Yogyakarta.

Nursyamsi, S.Y. (2016). The Effect of Numbered Heads Together (NHT) Learning Strategy On The Retention Of Senior High School Students In Muara Badak, 
East Kalimantan, Indonesia. European Journal of Education Studies. Volume 2, Issue 5

Rezeka, K. S, dkk. (2016). Penerapan Model Quantum Teaching pada Pembelajaran Persamaan Kuadrat di Kelas VIII SMPN 9 Banda Aceh. Jurnal Ilmiah Mahasiswa Pendidikan Matematika, 1(1), 98 - 110.

Sugiyono. 2012. Metode Penelitian Kuantitatif Kualitatif dan R\&B. Bandung: Alfabeta.

Ulandari, et al. (2017). Improving Learning Outcomes of Linear Program with Quantum Teaching Model at Grade X Students SMK-BM PAB 3 Medan Estate. International Journal of Sciences: Basic and Applied Research (IJSBAR), 00 (1).

Wahyuddin (2017). Penerapan Model Pembelajaran Numbered Head Together (NHT) pada Siswa Kelas V SD Negeri 75 Ujungpero Kecamatan Sabbangparu Kabupaten Wajo Suska Journal of Mathematics Education, 3(1), 57 - 66.

Yuhasriati \& Yulianti. (2015). One Variable Linear Equetion Teaching By Quantum Teaching In Seventh Grade Of MTsN Tungkob Aceh Besar. Improving Human Resources Quality Through Research And Development In The Era Of AFTA. International Conference Serambi Mekkah University: Banda Aceh. (355-359) 